\title{
How States Make Race: New Evidence from Brazil
}

\author{
Stanley R. Bailey,, Fabrício M. Fialho, ${ }^{\text {b Mara Loveman }}{ }^{c}$ \\ a) University of California, Irvine; b) Sciences Po Paris, France; c) University of California, Berkeley
}

\begin{abstract}
The Brazilian state recently adopted unprecedented race-targeted affirmative action in government hiring and university admissions. Scholarship would predict the state's institutionalization of racial categories has "race-making" effects. In this article, we ask whether the Brazilian state's policy turnabout has affected racial subjectivities on the ground, specifically toward mirroring the categories used by the state. To answer, we conceptualize race as multidimensional and leverage two of its dimensions-lay identification and government classification (via open-ended and closedended questions, respectively)-to introduce a new metric of state race-making: a comparison of the extent of alignment between lay and government dimensions across time. Logistic regression on large-sample survey data from before the policy turn (1995) and well after its diffusion (2008) reveals an increased use of state categories as respondents' lay identification in the direction of matching respondents' government classification. We conclude that the Brazilian state is making race but not from scratch nor in ways that are fully intended.
\end{abstract}

Keywords: race-making; census; race; affirmative action; state; multidimensionality

Citation: Bailey, Stanley R., Fabrício M. Fialho, and Mara Loveman. 2018. "How States Make Race: New Evidence from Brazil." Sociological Science 5: 722751.

Received: September 4, 2018

Accepted: September 27, 2018

Published: November 26, 2018

Editor(s): Jesper Sørensen, Delia Baldassarri

Dol: $10.15195 /$ v5.a31

Copyright: (C) 2018 The Author(s). This open-access article has been published under a Creative Commons Attribution License, which allows unrestricted use, distribution and reproduction, in any form, as long as the original author and source have been credited. (0)(1)
$\mathrm{T}_{\mathrm{T}}^{\mathrm{T}}$ the turn of the twenty-first century, the Brazilian state embarked upon an unprecedented public policy initiative that introduced race-targeted affirmative action into government hiring and university admissions. The state's embrace of race-targeted affirmative action upended more than a century of official rejection of the use of racial categories in public policy. To be sure, the Brazilian government was not completely "color-blind" prior to its recent embrace of affirmative action. For example, the state had long collected racial statistics in the census and denoted the "color" of infants on birth certificates. But the new affirmative-action policies represented the first time since at least the abolition of slavery in 1888 that the Brazilian state institutionalized racial categories in domestic public policy in ways that tied individual racial classifications directly to the distribution of material resources and opportunities. ${ }^{1}$ The Brazilian state's explicit recognition of racial inequality as a major social problem, and its readiness to implement race-targeted social policy as a means to address it, represented a radical shift in the Brazilian state's approach to governance.

Although most observers were caught off guard by the Brazilian state's turn to race-targeted policy, there are now several compelling post hoc accounts of the political struggles that undergirded and then followed the turnabout (Htun 2004; Telles 2004; Loveman 2014; Peria and Bailey 2014; Paschel 2016). But there is still much to learn about the varied repercussions of the Brazilian state's historic embrace of race-targeted public policy. Initial research on the effects of these policies focuses on whether they have generated increases in the representation of nonwhites in occupational and educational spaces (Guimarães 2010). Beyond its effects on the demographic distribution of individuals in different institutional 
spaces, it is also important to understand whether and how the Brazilian state's de jure institutionalization of racial categories affected racial identification dynamics on the ground. This is both an important substantive question for understanding social change in contemporary Brazil and an important theoretical question for understanding how states contribute to the construction of racial boundaries.

A growing literature suggests that states play a central role in "making race" (Bourdieu 1985; Fields 1990; Omi and Winant 1994; Posel 2001; Wacquant 2002; Bailey 2008; Loveman 2014). States are certainly not the only actors or sites of race-making, but existing scholarship underscores states' historically distinctive capacity to make some social boundaries appear more natural and salient than others through the official recognition and institutionalization of particular categorical divides. This literature generally locates a key mechanism of race-making in states' administrative use of racial categories in varied bureaucratic domains, from identity cards and censuses to de jure segregation and discrimination. States that use racial categories in multiple institutional contexts and link individuals' racial classification directly to access to opportunities or resources are especially likely to influence racial boundaries and subjectivities over time (Lieberman and Singh 2012). Of particular interest to this article, states' race-making capacity may be evidenced through citizens becoming more likely to use state racial categories to identify themselves and others (Bailey 2008; Lieberman and Singh 2012; Francis and Tannuri-Pianto 2015).

Although there are sound theoretical reasons to expect that states can cue race to become a symbolically and materially salient social boundary, there is a surprising paucity of studies that assess empirically whether or when states' use of racial categories affects subjectivities or symbolic boundaries on the ground. To assess whether the institutionalization of racial categories through race-targeted social policy has generated new subjectivities on the ground in Brazil, we draw on advances in the sociological conceptualization of race as a multidimensional construct (Telles and Lim 1998; Harris and Sims 2002; Saperstein 2008; Bailey, Loveman, and Muniz 2013; Roth 2016). We leverage two specific dimensions, lay identification and government classification, and introduce a new metric of state race-making: a comparison of the extent of alignment between lay and government racial dimensions across time. The use of official categories for informal classification is not a given (Prewitt 2002; De Zwart 2005; Lieberman and Singh 2012; Emigh, Riley, and Ahmed 2016; Roth 2016); moreover, the historical misalignment of these two dimensions in Brazil is well documented (Oliveira, Araújo, and Porcaro 1985; Harris et al. 1993; Silva 1996). Importantly, our data capture a time span from just before the unprecedented institutionalization of race-targeted social policy (1995) and approximately a decade into its introduction and diffusion (2008). We argue that change in dimension alignment across a period that witnessed a clear shift from historical nonracial public policy to strong institutionalization of race in public policy enables an approximation of whether and to what extent the Brazilian state is shifting individuals' subjectivities toward mirroring state categories (i.e., making race). 


\section{States and Race-Making}

A substantial body of literature argues that states play a central role in the social construction of racial cleavages (Bourdieu 1985; Burleigh and Wippermann 1993; Jenkins 1994; Omi and Winant 1994; Marx 1998; Mamdani 2001; Goldberg 2003; Tilly 2004; Golub 2005; Bailey 2008; Lieberman and Singh 2012; Loveman 2014; Suzuki 2016; Fialho 2017; Lieberman and Singh 2017; Liebler et al. 2017). ${ }^{2}$ State racemaking generally involves the institutionalization of racial categories across various bureaucratic domains. These include national censuses (Nobles 2000; Kertzer and Arel 2002; Goldberg 2003; Hochschild and Powell 2008; Morning 2008; Loveman 2014; Mora 2014; Lieberman and Singh 2017), identity cards and registries (Longman 2001; Posel 2001; Uvin 2002), public policy (Davis 1991; Ford 1994; Marx 1998; Golub 2005; Bailey 2008), immigration policy (Haney-López 1996; Fitzgerald and CookMartín 2014), and legal statutes and constitutions (French 2009).

When a state institutionalizes racial categories in a given bureaucratic or policy domain, this institutionalization can act as a "switching mechanism" that triggers an increase in the salience of particular social boundaries and a corresponding set of social identities relative to others (Lieberman and Singh 2017:6). ${ }^{3}$ For example, Lieberman and Singh (2012:6) posit that the institutionalization of racial categories in national censuses "encourages the adoption of a particular 'mental model,' 'schema,' or 'cognitive frame,' such that particular cleavages are deemed relevant." 4 Of course, the census per se may be a relatively weak form of state institutionalization of racial categories. In most countries, censuses only take place every 10 years, and individual responses are aggregated and anonymized; thus, the official categories may be experienced as irrelevant to most individuals' lives most of the time.

Historically and comparatively, states vary gradationally in the strength or weakness of their institutionalization of ethnic or racial categories. When racial categories are used by states across multiple administrative or policy domains, their salience for daily life is more likely to register within the population (i.e., to produce meaningful consequences for racial category membership). Those cases may constitute strong forms of the institutionalization of racial categories (Lieberman and Singh 2012). The United States, for example, is generally analyzed as a clear case of strong institutionalization through its origin and trajectory as a slave society (Fields 1990; Wacquant 2002) and later postabolition embrace of Jim Crow legislation (Davis 1991; Marx 1998). These state-sanctioned practices in the United States created and recreated white and black boundary distinctions through efforts to make the black-white boundary clear (by legal definition), official (through institutionalization), and consequential (by systematically linking individual racial classification to opportunities for privilege versus disadvantage).

States necessarily differ in how their racial projects and corresponding modes of institutionalizing racial categories interface with (and become partially constituted by) distinctive historical legacies, previously salient ethnoracial understandings, and an array of nonstate actors and their race-making projects (Bourdieu 1985; Fields 1990; Eschbach, Supple, and Snipp 1998; Mora 2014; Paschel 2016). Such is the case that race-making effects are always contingent and varied. For example, 
states may be more likely to make race-that is, to affect the salience or location of racialized social boundaries on the ground-when their projects align with contemporaneous racial projects involving nonstate actors (Jenkins 1994; Bailey 2008; Fialho 2017). In practice, race-making is often overdetermined by overlapping contexts of categorization (Tilly 2004:206).

A critique of the language of race-making is that it enables broad claims that are difficult to ground empirically or compare across cases (Lieberman and Singh 2012; Emigh et al. 2015; Lieberman and Singh 2017). Assessing the race-making consequences of any given racial project is certainly a methodological challenge. Though the link between state actors and the deployment of official racial schemes is often clear in historical records, what is usually less clear is the link between official categorization schemes and everyday understandings of race (Emigh et al. 2015). We posit that a minimum evidentiary criterion for assessing state-led race-making affecting subjectivities on the ground would be systematic evidence of how individuals identify themselves before a new racial project was initiated in comparison to how they identify afterward. ${ }^{5}$

In this article, we focus on the Brazilian state's sudden shift from weak to strong institutionalization of racial categories in public policy as a possible switching mechanism that triggered changes in individuals' racial subjectivities on the ground. To do so, we leverage a dynamic conceptualization of race as a multidimensional construct and exploit the rare availability of data sources capturing two key dimensions of race-lay identification and government classification-in Brazil from two points in time: before and after the shift from weak to strong institutionalization. In what follows, we lay out our analytic framing and strategy, followed by a brief overview of the contours of Brazil's new racial project and a description of our data sources.

\section{Multidimensionality and Dimension Alignment}

Our conceptualization and empirical operationalization of state-led race-making builds on recent advances in sociological analyses of race as multidimensional (Harris and Sims 2002; Telles 2002; Bailey 2008; Saperstein 2008; Bailey et al. 2013; Roth 2016; Liebler et al. 2017). This framing views race as a social construct with multiple facets, understandings, and markers. For example, how an individual self-identifies may differ from the way that same person is seen by others (Telles and Lim 1998). Both racial lenses can be important in a context's racial dynamics; they simply constitute analytically distinct dimensions. Other racial dimensions include, for example, classification by skin color and ancestry (Roth 2016).

Conceptualizing race as multidimensional also constitutes an analytic strategy; a comparison of the extent of correspondence across distinct dimensions of race yields novel empirical findings about stratification dynamics and patterns of racial identification. For example, scholars analyze how racial disparities in consequential social outcomes appear more severe when race is operationalized by others' classification versus self-classification (Telles and Lim 1998; Saperstein 2008; Bailey et al. 2013). Other scholars examine racial boundary salience by comparing levels of correspondence between self-classification and the interviewer's classification 
(Telles 2002; Bailey 2009) and between individuals' self-classification across different social spaces (Harris and Sims 2002; Sansone 2003).

Building on this line of work, we propose "dimension alignment" as a concept and an empirical metric for the assessment of claims about race-making. In this study, we focus on the extent of alignment between two racial dimensions: colloquial self-identification (lay identification) and self-classification in the state's official scheme (government classification). These dimensions are captured in our study by open-format and closed-format survey questions, respectively, as we lay out below. We posit that assessing change in the alignment of these two dimensions over time (i.e., the extent to which lay identification mirrors government classification) provides an empirical basis for evaluating the proposition that a state is in the process of race-making. Theoretical support for our dimension alignment concept rests in part on the premise of Lieberman and Singh (2012:4) that evidence of state-led race-making can be in the form of citizens becoming "less likely to use hybrid or other categories and more likely to use state labels to identify themselves and to recognize coethnics."

The case of Brazil is particularly apt for demonstrating the usefulness of the concept and empirical metric of dimension alignment for assessing states' racemaking for at least two core reasons. First, although the Brazilian state has used racial categories in most of its national censuses since its first in 1872 (Nobles 2000), researchers note the low resonance of these categories in everyday racial identification dynamics (Harris et al. 1993; Sansone 2003), thereby suggesting only weak institutionalization effects. Second, these census categories have been used broadly for the implementation of race-based affirmative action in university admissions and government hiring, thereby suggesting a move to strong institutionalization. Hence, the Brazilian case provides leverage to ask: Did the state's new policies act as a switching mechanism, increasing the salience of its official categories for lay identification? Before addressing this question empirically, we briefly lay out the contours of Brazil's racial project in this period.

\section{The Brazilian State's Embrace of Affirmative Action}

Brazilian state discourse long touted a national population not beset by the types of discriminatory practices that plagued the United States. Indeed, throughout much of the twentieth century, Brazil was often described as a blended nationa mixture of descendants of African slaves, Europeans, and Amerindians-and as an example to the world of "ethnic democracy" (Freyre 1959). In the 1950s, Brazil's international reputation for perceived racial conviviality motivated the United Nations Educational, Scientific and Cultural Organization (UNESCO) to sponsor a series of studies to understand how the case of Brazil might serve as a model in a world vividly scarred by German Nazism and de jure discrimination in the United States (Maio 2001). ${ }^{6}$ Soon after those studies, a military dictatorship ruled Brazil (1964-1985), creating a hostile climate for social critique. Nonetheless, in the dictatorship's waning years, negro (or Afro-Brazilian) movement actors increasingly challenged official discourse on racial democracy (Mitchell 1985; Santos 1999). With the return to political democracy in the mid-1980s, negro movement 
antidiscrimination agendas began to pay off; in 1988, the 100-year anniversary of slavery's abolition, the National Constitutional Assembly voted to make racism a crime punishable by imprisonment.

However, not until Fernando Henrique Cardoso's presidency (1995-2003) did the federal government begin to seriously acknowledge racial discrimination and inequality in Brazil and work more closely with negro movement actors (Bailey 2009; Campos 2013). The most important event in advancing the new relationship was Brazil's extensive participation in the United Nation's 2001 World Conference against Racism. The mobilization of social movement actors and sectors of the Brazilian government in the different stages of the conference's planning and execution lent significant momentum to the discussion of a national-level plan to combat racial inequality, as it also provided the needed push toward the implementation of race-targeted approaches.

On the heels of the 2001 conference, federal and state government actors began implementing affirmative-action policies by means of executive order and legislation across various bureaucratic domains (Htun 2004; Telles 2004; Campos 2013; Peria and Bailey 2014; Paschel 2016). Perhaps the greatest social impact came from the rapid and massive implementation of racial quotas in university admissions. The cascading process of implementation formally began with a law passed by Rio de Janeiro's State Assembly in 2001. In the months and years to follow, other public universities and state legislators moved to enact similar racial quota policies. By 2005, 24 of the 95 public universities in Brazil had adopted affirmative-action policy in admissions, and by 2007, that number had grown to 37 (Peria and Bailey 2014). In the years that followed, practically all institutes of higher learning in Brazil adopted racial quotas due to either state-level policy or federal mandate (Lehmann 2018). ${ }^{7}$

The targeted populations for quotas in general are individuals who self-classify in the government's official (census) scheme as being in the brown (pardo) or the black (preto) categories (Eurístenes, Feres Júnior, and Campos 2016; Feres Júnior et al. 2017). These two population segments account for just more than 50 percent of Brazil's population, according to its 2010 census, at 47.3 and 7.6 percent, respectively (Instituto Brasileiro de Geografia e Estatistica 2011). ${ }^{8}$ Eligibility for racial quotas in university admissions specifically requires an individual to apply to the parallel quota admissions process and generally to self-classify as either pardo or preto on a quota declaration form. ${ }^{9}$ However, some race-targeted policies use the term negro, either alone or in conjunction with the official census categories pardo and preto (Bailey 2008; Campos 2013; Peria and Bailey 2014). For example, the policy at the University of Brasília stated, "a candidate should be of pardo or preto color and declare oneself negro" (University of Brasilia 2004). The preto and the negro labels have been considered interchangeable historically in colloquial understandings (Feres Júnior 2004). Nonetheless, in contrast to preto, which is considered a color term, negro has been embraced and advanced by the Brazilian negro movement as an umbrella racial category for all individuals of perceived African origin, generally defined as individuals self-classifying in the state's census categories as either pardo or preto (Nobles 2000; Nascimento and Nascimento 2001; Paschel 2016). ${ }^{10}$

The implementation of these new race-targeted policies in Brazil has been complicated by several factors, including the fact that the racial vocabulary Brazilians 
use to self-identify in everyday life does not neatly align with the state's official scheme (Maio and Santos 2005; Schwartzman 2009; Campos 2013). On the one hand, the pardo and preto beneficiary categories represent flat, arid color terms, and legacies of racial whitening projects mark both terms with specifically negative connotations (de Oliveira e Oliveira 1974). As a result, these two terms have had low levels of attachment, and in their stead, many Brazilians prefer noncensus terms for lay identification (Silva 1996; Sansone 2003). On the other hand, historically weak institutionalization of racial categories, combined with the continued ideological resonance of the idea of Brazil as a mixed-race nation, enables a flexibility of identification that generates considerable classificatory ambiguity (Telles 2002; Lieberman and Singh 2012).

It is no surprise then that Brazil's recent move toward strong institutionalization has stirred broad public debate. There have been numerous accusations and lawsuits alleging "racial fraud" against individuals considered by others to be branco (white) who self-classified as nonbranco for quota inclusion (Peria and Bailey 2014). As a result, beneficiary status is sometimes verified by controversial, specially constituted committees using photographs and/or in-person interviews (Lehmann 2018). Another contentious point was over precisely whether the state's move to strong institutionalization of racial categories would have race-making effects (Feres Júnior 2004; Fry and Maggie 2004; Maio and Santos 2005; Guimarães 2005; Bailey 2008; Schwartzman 2009). It is clearly the case that historical and ongoing social stratification processes have produced racialized social cleavages and inequalities of varying intensities in Brazil (Hasenbalg 1985; Telles 2004; Bailey et al. 2013). It remains an open question whether the introduction of race-targeted policies that aimed to mitigate these cleavages acted as a switching mechanism that significantly affected Brazilians' racial subjectivities toward mirroring the racial categories used by the state.

\section{Data and Methods}

To explore possible shifts in racial subjectivities on the ground in Brazil, specifically to assess if such shifts are in the direction of mirroring state categories, we examine data from two face-to-face surveys collected by Datafolha Instituto de Pesquisas, a major survey research institute in Brazil. Datafolha conducted the first survey in 1995 (Datafolha Instituto de Pesquisas 1995) and then repeated that survey in 2008 (Datafolha Instituto de Pesquisas 2008). Both are national samples stratified by geographic macroregions of the urban population age 16 years and older. ${ }^{11}$ The complete sample for 1995 consists of 5,081 respondents sampled across 121 municipalities and for 2008 consists of 2,982 respondents across 212 municipalities. $^{12}$

Uniquely, these surveys included two questions regarding respondents' selfidentification that captured two distinct dimensions of race. Respondents were asked first to self-identify their color and/or race in an open-ended question. ${ }^{13} \mathrm{We}$ label this dimension lay identification. An ensuing question asked respondents to self-identify their color and/or race in a closed-ended question containing only the official state categories of Brazil's census. ${ }^{14}$ We label this dimension government classification. Question order was important; open-ended responses were 
not contaminated by responses to the closed-format items. Dimension alignment occurs when responses are consistent across survey questions that capture different dimensions of racial identification. Our specific interest here is comparing the extent of alignment between lay identification and government classification at two points in time: one before the introduction of race-targeted social policy by the state and one more than a decade after its widespread implementation. An increase in the alignment of lay identification preferences with government classifications across this period provides strongly suggestive evidence of race-making (Lieberman and Singh 2012, 2017).

We begin our analysis with frequency distributions of lay identification (open format) and government classification (closed format) in 1995 and 2008, followed by their cross-tabulation. We then employ logistic regressions to further explore dimension alignment by regressing lay identification on select respondent characteristics, including respondents' government classification, and survey year. This analytic strategy allows for an examination of model coefficients, as well as the estimation of propensities for respondents' racial dimensions to align (for respondents' lay identification and government classification to match), and how dimension alignment propensities change across time.

Our dependent variable of lay identification is derived from the open-ended question. The six most frequent responses in both survey years were branco, pardo, and preto (all of which are official census terms) as well as moreno, moreno claro, and negro (the latter three are not census terms). These six terms together make up 94 percent of the sample in 1995 and 95 percent in 2008. We recode responses to form a dichotomous outcome: " 1 " for those whose responses in the open-ended question (lay identification) matched their responses in the closedended question (government classification) and " 0 " for all other responses (for which lay identification and government classification did not match).

We use self-classification as branco, pardo, or preto in the official closed format (or government classification) as a predictor of choices in the open format (or lay identification) as noted above. Pardo is the reference category. Because of the small number of respondents self-classifying as being of Asian descent (amarelo) or indigenous (indigena), the two remaining census categories in Brazil, these are not included in our analyses. The inclusion of government classification as an independent variable enables the estimation of propensities for those self-classifying as brancos, pardos, and pretos in the closed format to respond with those same categories in the open-ended question (i.e., dimension alignment).

Covariates also included in our regression models are education, household income, gender, age, and region. Education is coded in three levels of educational attainment: people who completed up to elementary school (reference category), those who have some or complete high school education, and those with some college or complete college education. Household income is measured in four levels of monthly minimum wages (MWs): ${ }^{15}$ (1) up to two monthly MWs (reference category), (2) more than two and up to five MWs, (3) more than five and up to 10 MWs, and (4) more than 10 MWs. Gender is a binary variable coded as female or male (reference category). Age is a continuous variable measured in years and recoded such that zero is a 16-year-old respondent and one refers to 
a 75-year-old respondent in the samples; ${ }^{16}$ the coefficient associated with age therefore captures the difference between a teenager and an elder without further calculations. ${ }^{17}$ Region is a categorical variable original to the data set and is coded in four categories, Southeast (reference category), South, Northeast, and North and/or Central-West (CW). Our preferred models also include two interaction terms: government classification by education and government classification by age. $^{18}$

We run separate models for each survey year, 1995 and 2008, allowing for the approximate comparison of propensities across that 13-year period. We then use sample pooling of the two survey years to test the direction and the significance of year (1995 versus 2008) on dimension alignment and its interaction with government classification. ${ }^{19}$ In our design, the year variable proxies a period effect (Sewell 1996; Lieberman and Singh 2017) — that is, the effect of the Brazilian state's move from non-race-targeted to race-targeted public policy on how Brazilians' racially identify (Bailey 2008; Francis and Tannuri-Pianto 2015).

\section{Findings}

\section{Descriptive Statistics}

We begin with a comparison of the racial composition of the Brazilian population in 1995 and 2008 based on the closed-format question using government classifications (Figure 1). Vertical bars represent 95 percent confidence intervals. The comparison reveals a decline in the percent of Brazilians who self-identify as branco by almost 13 percent in the 13-year period. On the other hand, pardo and preto experienced an expansion of 9.6 and 3.4 percent, respectively, between 1995 and $2008 .^{20}$ These data show that the racial composition of the Brazilian population is in flux in this period with regard to government classification queried through a closed-ended question. These shifts seem to suggest a constriction of the boundary that delineates who self-identifies as white in Brazil and an expansion of the boundary that delineates who is pardo or preto.

The temporal correspondence of these shifts with the implementation of racetargeted social policies could be read as suggestive evidence of state-directed racemaking in Brazil. However, this comparison of the population distribution over time based on a closed-format question does not tell us anything about how Brazilians self-identify when not restricted to government classifications. An assessment of how lay identification preferences align with government classifications over time provides a more rigorous evidentiary threshold for assessing whether the state is making race by shifting salient social boundaries and individual subjectivities. Hence, we leverage a second dimension of racial identification captured in these two surveys-lay identification in an open-ended format-for further insight.

Percentage distributions from the open-ended question (or lay identification; Figure 2) also show important changes over time. Vertical bars represent 95 percent confidence intervals. Whereas the mention of the preto category as individuals' lay identification appears relatively stable across 1995 and 2008, significant changes occur in the choice of branco and pardo. There is a reduction of just more than 5 


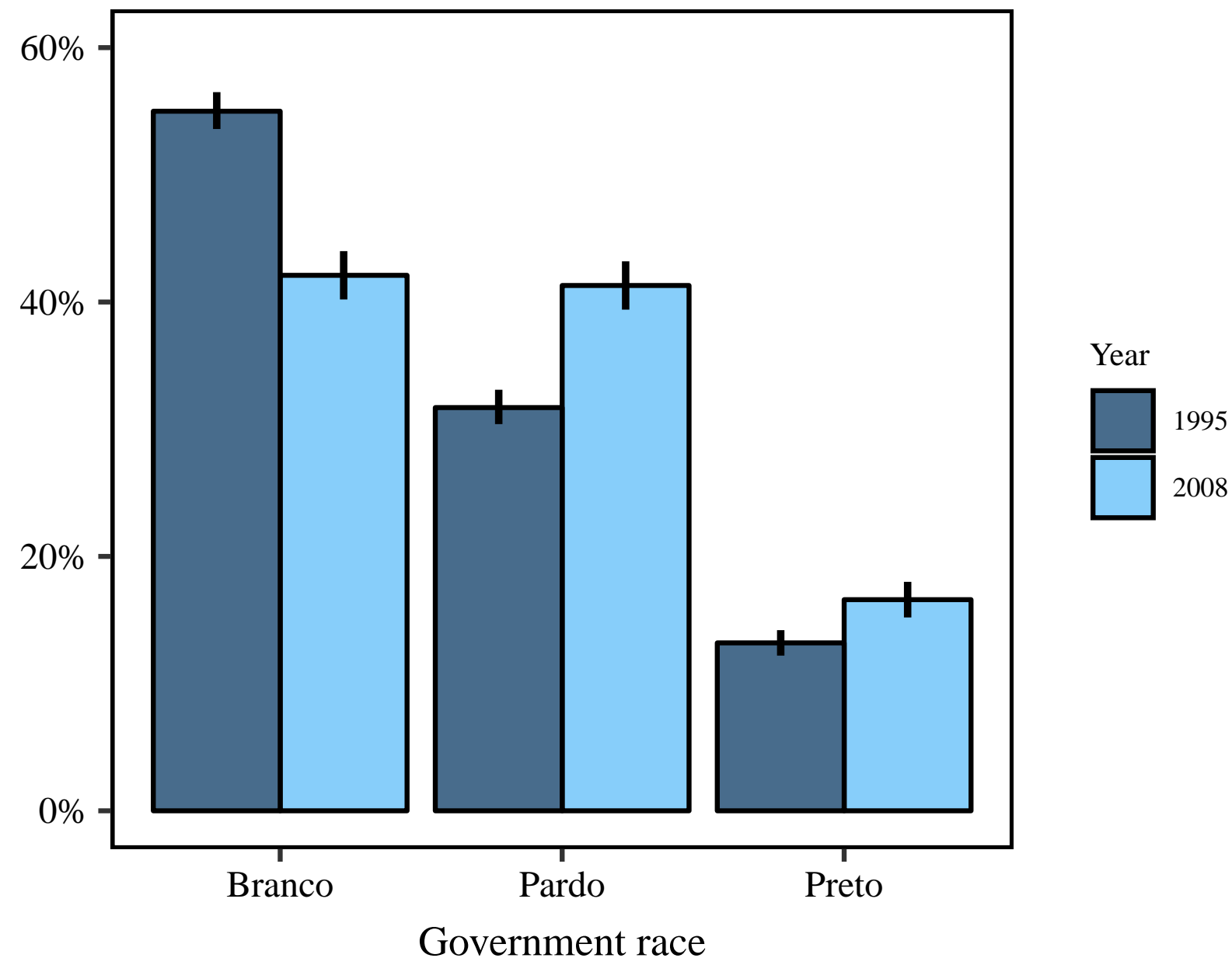

Figure 1: Racial composition by government classification, 1995 and 2008.

percent in the mention of the branco category as individuals' lay identification and a striking increase in those choosing to self-classify as pardo. The choice of pardo in the open-ended question increases from 6.4 percent in 1995 to 19.5 percent in 2008. Altogether, the percentage of the population choosing a government classification category as their lay identification increased from 52.4 percent in 1995 to 60.4 percent in 2008. These descriptive results indicate that an increased alignment of lay identification preferences with government classifications across the study period occurred in Brazil.

Figure 3 shows three cross tabulations: government classification of brancos (Panel A), pardos (Panel B), and negros (Panel C) by lay identification. Vertical bars represent 95 percent confidence intervals. From Panel A, the results show that the percentage of the population that self-classified as branco for both their government classification (closed-format question) and their lay identification (open-ended question) is high overall; in addition, it increased by about 10 percent from 1995 to 2008 (from 73 percent to 83 percent, respectively). Panel B of Figure 3 also shows 


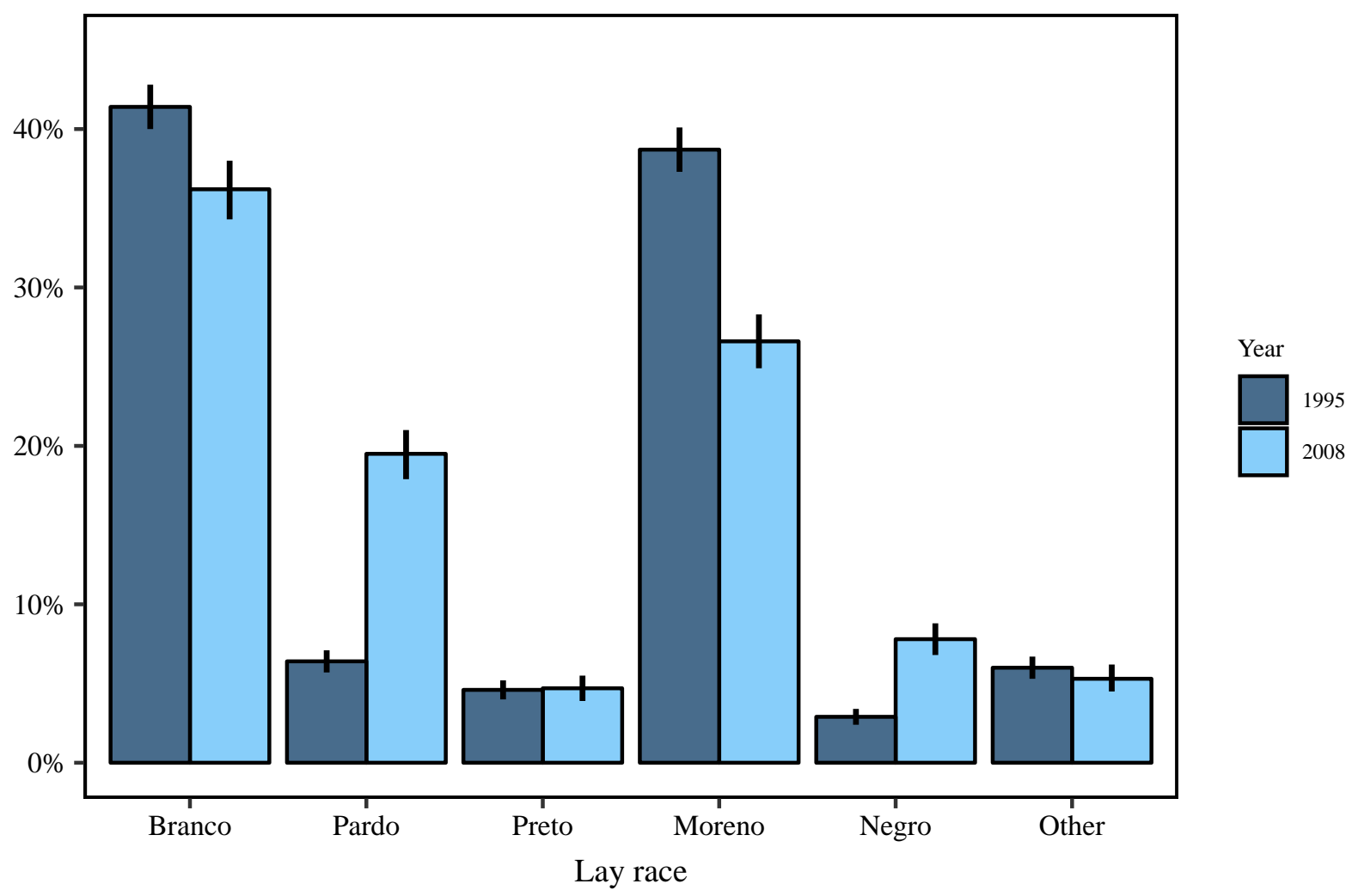

Figure 2: Racial composition by lay identification, 1995 and 2008.

that pardo dimension alignment increased between 1995 and 2008 (from 18 percent to 45 percent, respectively) and to a comparatively higher extent than for brancos. The almost threefold increase in pardo dimension alignment is striking considering that pardo has long been unpopular for expressing individuals' lay identification in Brazil (Silva 1996). Preto dimension alignment is also comparatively low compared to branco, as shown in Panel C; in fact, preto dimension alignment is by far the lowest among government classification categories in 2008. Moreover, in contrast to the increasing trends of dimension alignment for brancos and pardos, preto alignment actually decreased slightly between 1995 and 2008, from 29.5 percent to 27 percent, respectively.

\section{Multivariate Analysis}

Using logit regression models, Figure 4 presents graphed coefficients for variables predicting respondents' alignment of lay and government race in 1995 and 2008. The horizontal lines (or error bars) passing through the symbols for the coefficients (circles for 1995, diamonds for 2008, and squares for the pooled model) represent 95 percent confidence intervals; when a coefficient's bar crosses the vertical line marked " 0, " the coefficient is not significant $(p>0.05)$. The variable names on the $y$ 

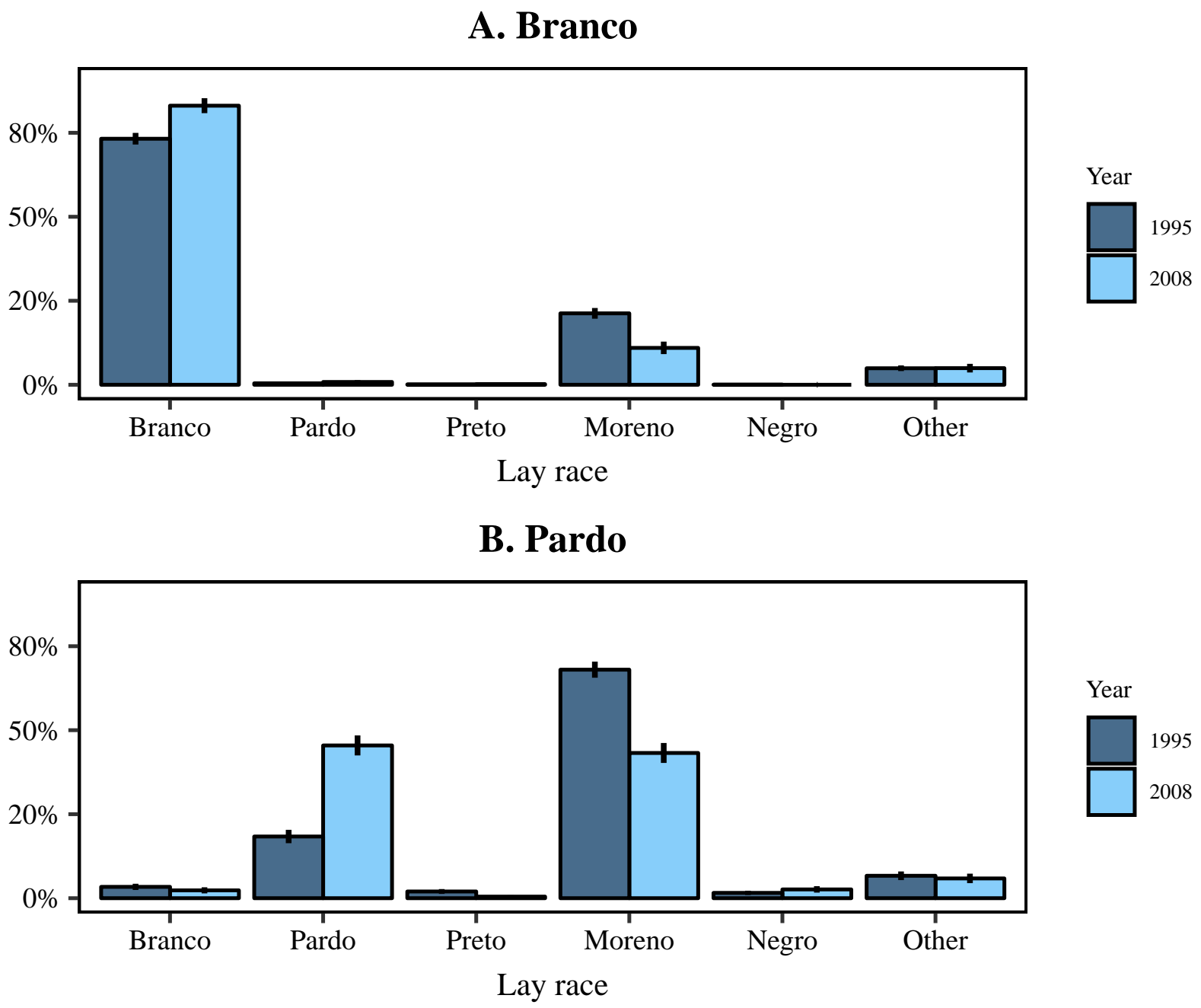

\section{Preto}

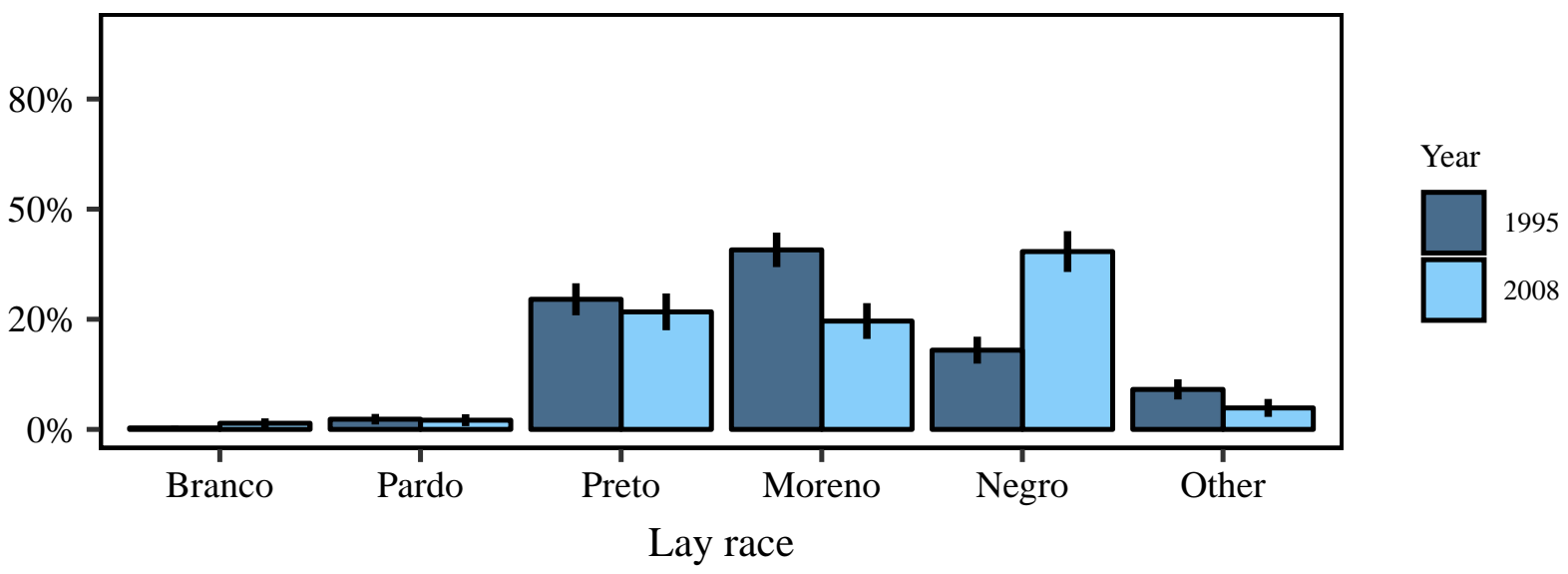

Figure 3: Government classification by lay identification, 1995 and 2008. 
axis marked with an asterisk indicate that the regression coefficients for 1995 and 2008 are statistically different from each other ( $p<0.05$; Gelman and Stern 2006).

We begin examining the coefficients for government classification categories as predictors of lay identification choice. Our results are overall in line with the descriptive statistics. Compared to those who self-identify as pardo in the closedformat question (reference category), Figure 4 shows that dimension alignment was significantly more likely among those who self-identified as branco on the same question in both 1995 and 2008, whereas there is no statistical difference between pardos and pretos with regard to their levels of alignment when holding all other variables constant. Regression results are suggestive of a decline in alignment among pretos from 1995 to 2008, although coefficients do not differ statistically. Results from a separate model using pooled data and an interaction term between survey year and government classification (see square point estimates in Figure 4) also corroborate the descriptive statistics presented in Figure 3: From 1995 to 2008 and holding all other variables constant, there is stronger alignment growth among pardos than among brancos and a slight yet nonsignificant decline among pretos. ${ }^{21}$

Figure 5 shows average predicted probabilities for dimension alignment among government classification brancos, pardos, and pretos derived from our regression models. The average predicted probability for brancos is high in 1995 (0.74) and increased in 2008 (0.83). In stark contrast, the average propensity for dimension alignment among pardos in 1995 was relatively low (0.19); nonetheless, it showed a remarkable twofold increase in 2008 (0.46). Propensities among pretos for dimension alignment in 1995 and 2008 were somewhat stable (0.29 and 0.27, respectively). Taken together, these results clearly suggest changing subjectivities on the ground in Brazil, specifically changes in the likelihood of individuals to use government categories to identify themselves.

Figure 4 also shows that the likelihood that Brazilians' preferred lay identification matches their choice of government categories varies by education level, age, and income even as the overall likelihood of alignment for all Brazilians increased over time. With respect to education, our graphed coefficients show that higher levels of education, especially college education, are associated with higher levels of dimension alignment among pardos and brancos, and the correlation between education and alignment increases over time. However, the effect of education differs across government classification categories, namely between pretos and the other two populations, as illustrated by interaction terms. Government preto respondents with higher education present lower probabilities of alignment than their branco and pardo counterparts.

These dynamics can be seen clearly in the graphed predicted probabilities in Figure 6. Focusing on 2008, we see that the negative effect of education on dimension alignment for pretos dramatically contrasts its positive effect for brancos and pardos. The average expected propensity for those with an elementary education level who self-identify as preto to also identify as preto in the open-format question is 34 percent; however, it falls to just 7 percent for those with a college education. This negative education effect for pretos may reflect the broader preference for the term negro among more educated government classification pretos in Brazil, which is consistent with prior research (Bailey and Telles 2006). 


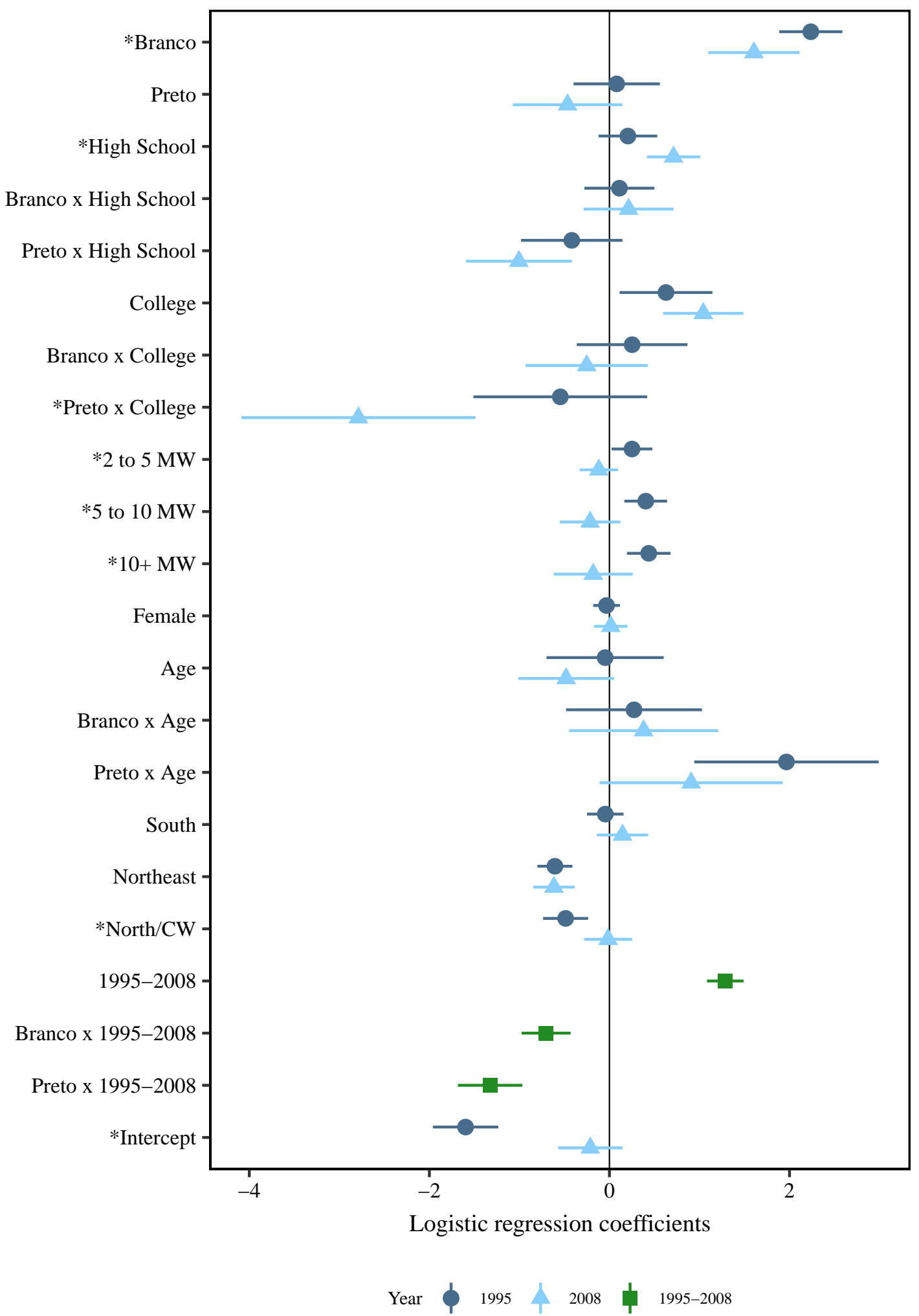

Figure 4: Logistic regression coefficients for the alignment of lay and government race, 1995 and 2008. 


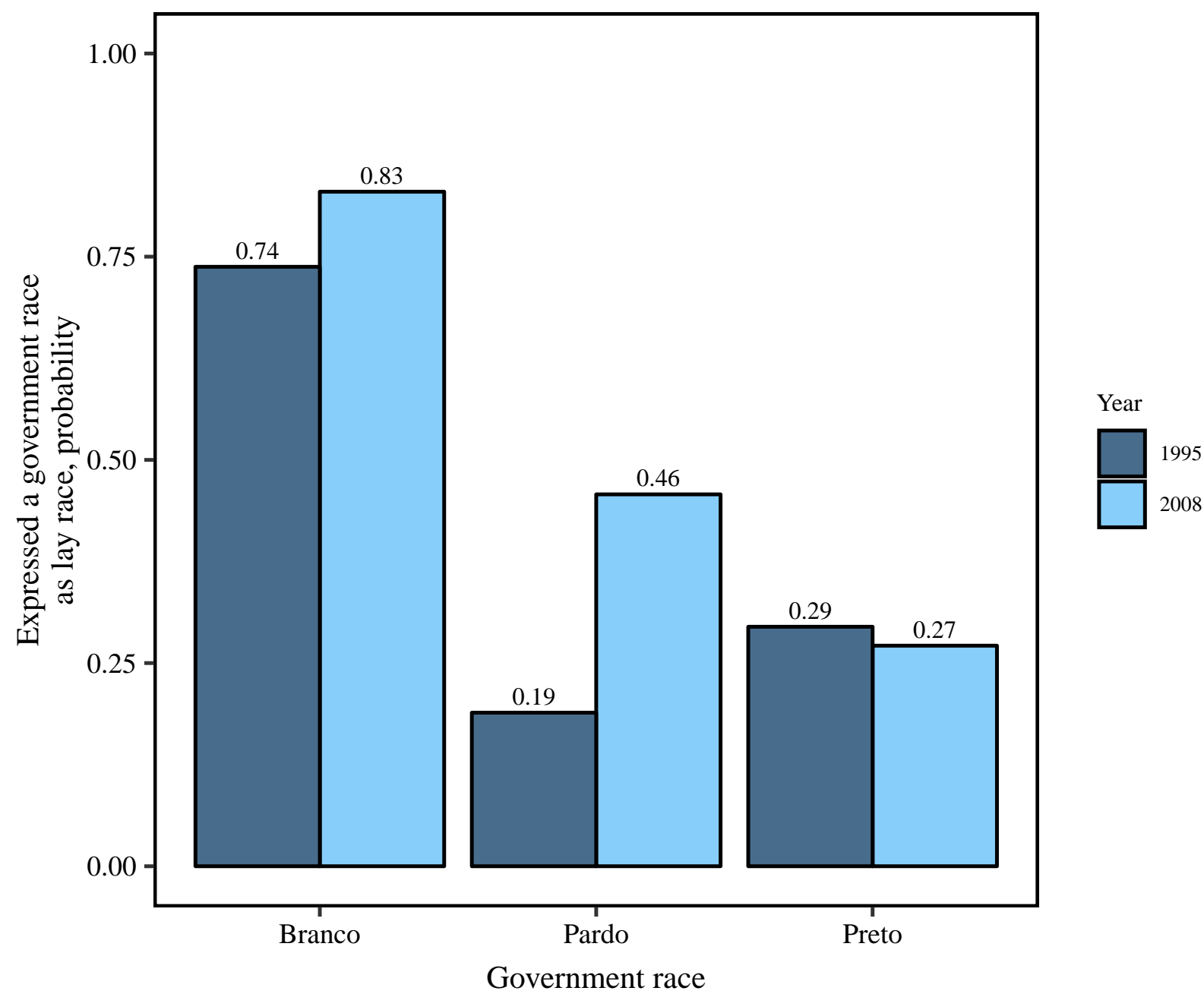

Figure 5: Average predicted probability for dimension alignment, 1995 and 2008.

The effect of age on dimension alignment also operates differently across government classification categories. Similar to education, the interaction effect of age with government classification reveals unique dynamics for preto dimension alignment. The graphed coefficients in Figure 4 reveal that only the interactive effect concerning pretos is positive and substantial (compared to pardos). ${ }^{22}$ The predicted probabilities reported in Figure 7 reveal that whereas the youngest among government classification pretos in the sample (16-24 years old) have a 0.24 probability for dimension alignment, that statistic is 0.37 for the oldest in the sample $(60+$ years old) in 2008. This specific age effect for government classification pretos likely reflects the greater embrace of the negro term among younger government classification pretos. That embrace may be in part a reflection of this population cohort's greater exposure to negrocentric urban youth culture (Sansone 2003) as well as their greater exposure to negro social movement activities related to affirmative-action policy in higher education in Brazil (Lehmann 2018). 


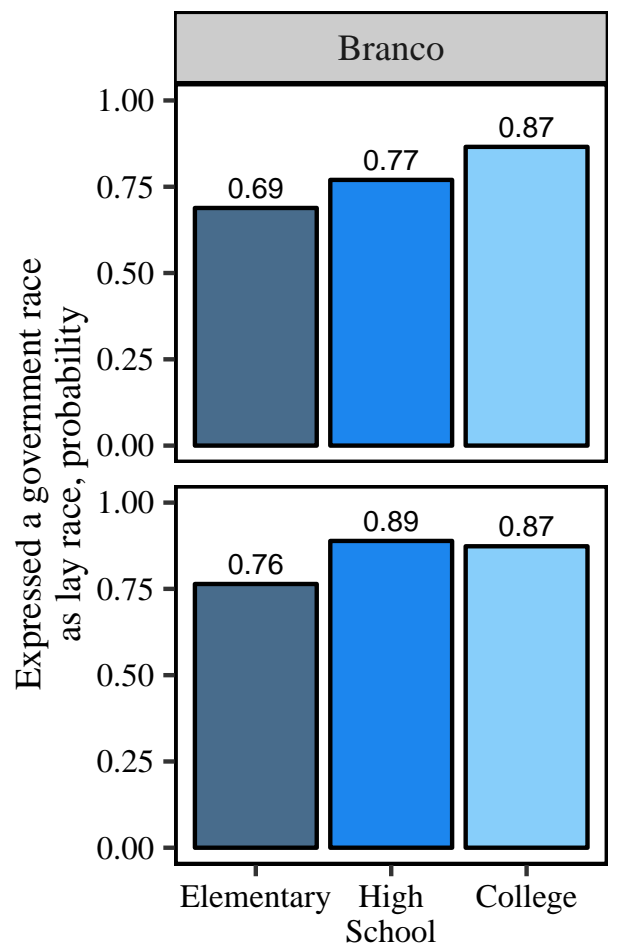

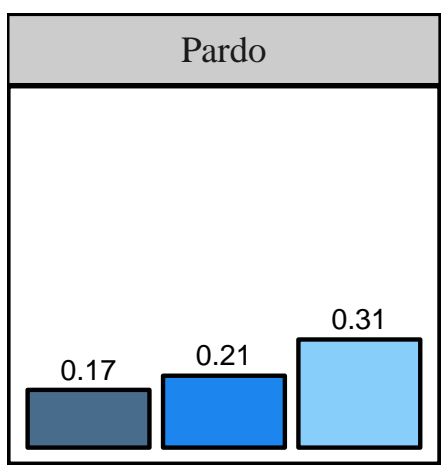

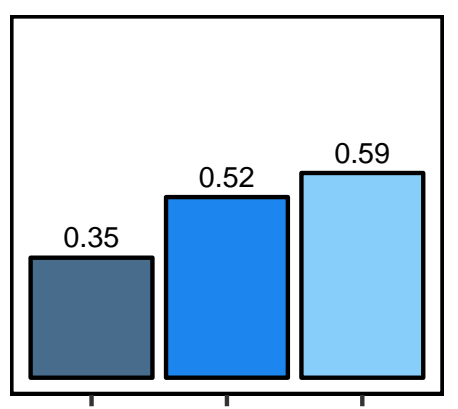

Elementary High College School
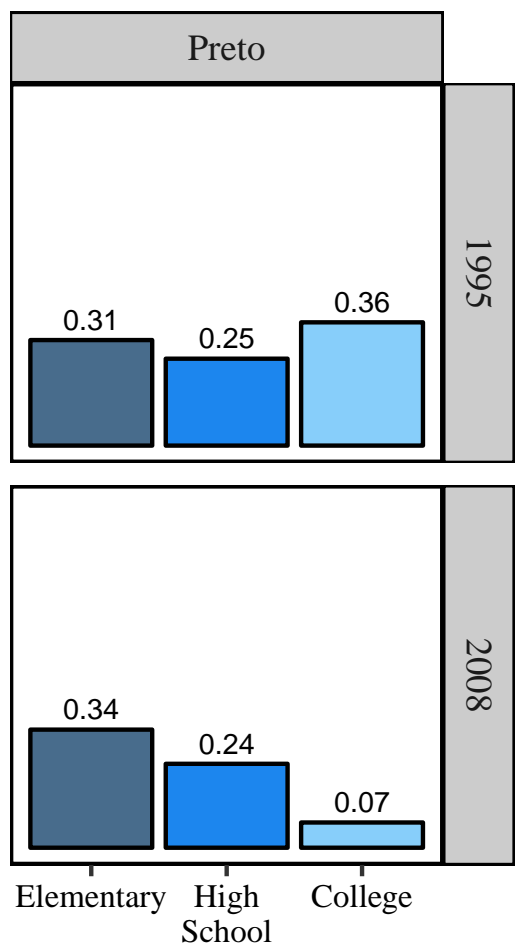

Government race

Education

Elementary High School College

Figure 6: Average predicted probability for dimension alignment by education, 1995 and 2008.

Whereas regression coefficients in Figure 4 show that household income was positive and significant in 1995 for dimension alignment, holding constant all other variables, it was neither in 2008. Gender was not significant in either survey year. Figure 4 also provides some evidence of the importance of region in dimension alignment. The strongest effect appears in the Northeast, which is negative and significant in 1995 and 2008, compared to the Southeast reference region. In both years, respondents from the Northeast show a lower probability to express a government classification as their lay identification compared to respondents from the Southeast and the South. Respondents from the North and Central-West regions also presented lower probabilities compared to those from the Southeast and South in 1995 but not in 2008. Results overall suggest that dimension alignment has been stronger in the two most economically developed regions in the country (i.e., the Southeast and South).

Most significantly in addressing our central question of whether the introduction of race-targeted social policy in Brazil has altered lay identification preferences in contexts in which Brazilians are not restricted to a choice of government categories, our results show clear evidence of a period effect on the alignment of government 

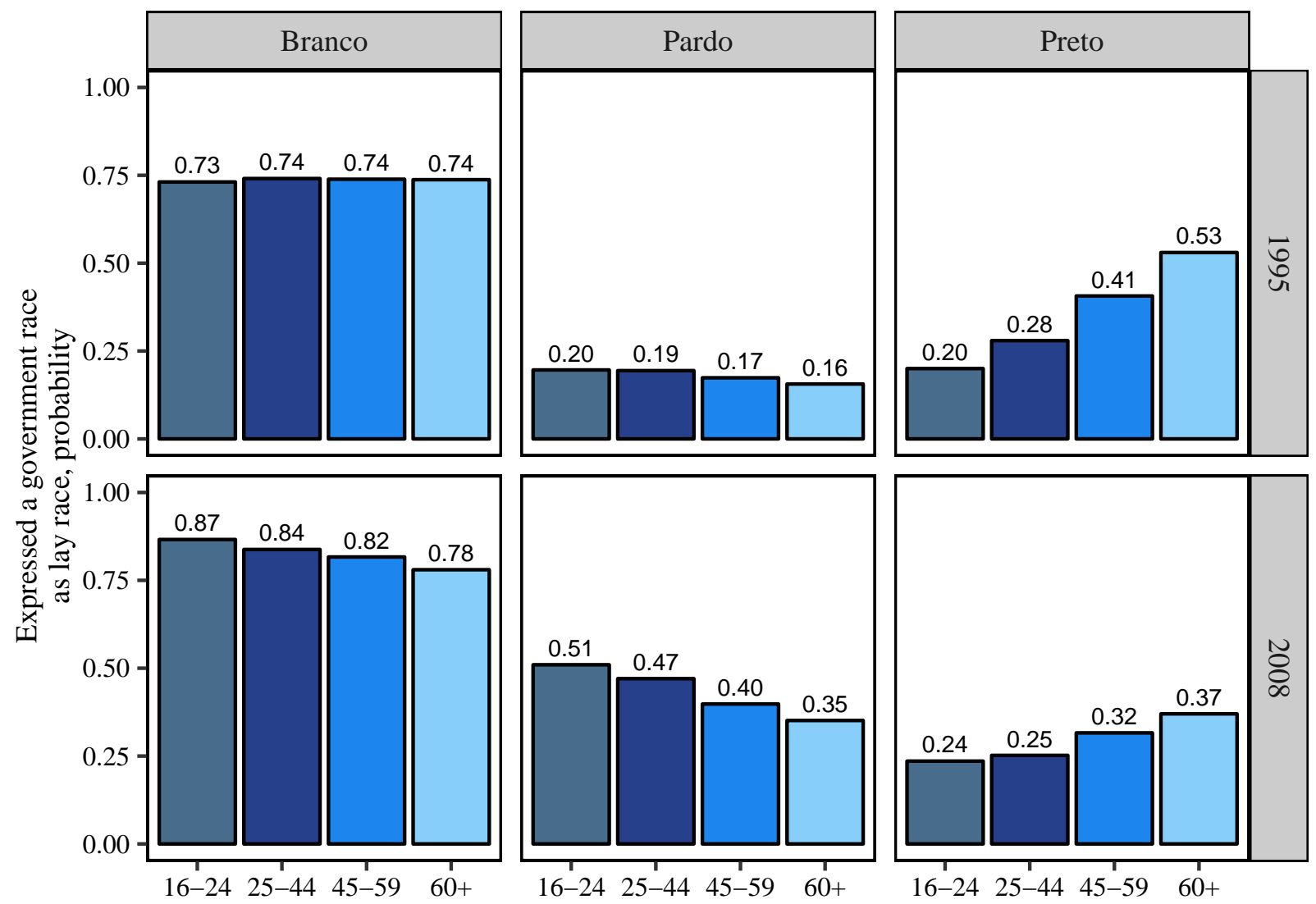

Government race

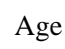
$16-24$ $25-44$ $45-59$ $60+$

Figure 7: Average predicted probability for dimension alignment by age, 1995 and 2008.

and lay classification choices. Specifically, the coefficient for year (denoted by the square symbol in Figure 4) is positive and significant, indicating that pardos (the reference group) are overall more likely to use government classification categories as their lay identification in 2008 compared to 1995, holding all other variables constant. A similar trend of increase in the use of government classification is also found among brancos, though the increase from 1995 to 2008 has been less dramatic for this group than the former. This finding is squarely in line with our descriptive analysis and with the comparison of separate regression models for 1995 and 2008 discussed above. For pretos, however, as shown in Figure 5, when other covariates are held constant, the period effect is nil. Such a result is consistent with the results in Figure 3, which indicate that the propensity for government classification pretos to also express preto as a lay identification remains relatively stable across time. Overall, all our analytic strategies converge in suggesting that the Brazilian state's 
adoption of race-targeted policies has changed racial subjectivities on the ground, though in some unanticipated ways and not uniformly across the population.

\section{Discussion}

We began by noting that substantial scholarship posits the power of states to mold the salient lines of "visions and division" within the populations that they govern (Bourdieu 1985; Burleigh and Wippermann 1993; Jenkins 1994; Marx 1998; Kertzer and Arel 2002; Goldberg 2003; Tilly 2004; Golub 2005; Bailey 2008; Lieberman and Singh 2012; Loveman 2014; Suzuki 2016; Fialho 2017; Lieberman and Singh 2017). Scholarship suggests that states make race through the institutionalization of racial categories across a varying number and type of bureaucratic or policy domains. When racial categories are used by the state in limited domains and without clear consequences tied to their use-that is, when the institutionalization of racial categories is weak - the salience of social boundaries delimited by state categories is likely to be low. In contrast, when states use racial categories in multiple domains and clearly link their use to the distribution of symbolic or material opportunities or resources-that is, when the institutionalization of racial categories is strong-the salience of boundaries that mirror state categories is likely to increase (Lieberman and Singh 2012, 2017). The Brazilian state moved from weak to strong institutionalization of racial categories when it began implementing racetargeted affirmative-action programs in universities and government employment. Accordingly, theories of state-directed race-making led us to expect an increased resonance of official racial categories for lay identification and increased salience of those racial boundaries demarcated by officially institutionalized categorical divides.

To gain empirical traction on the theoretical proposition that the Brazilian state was effectively making race, we argued the need for a novel analytic approach and an empirical metric. Our design leveraged the recent turn to conceptualizing and operationalizing race as a multidimensional social construct (Harris and Sims 2002; Bailey et al. 2013; Roth 2016). From that lens, we made the analytic distinction between government and lay dimensions: the former reflecting the state's vision and the latter reflecting racial subjectivities on the ground. Leveraging this distinction, we introduced the concept of dimension alignment to capture the extent to which a state's vision is mirrored in everyday racial subjectivities; furthermore, we suggest that evidence of increasing alignment between these two dimensions over time can constitute evidence of state race-making (Lieberman and Singh 2012).

We proposed that a minimum criterion for evaluating the proposition that a state engaged effectively in race-making would be systematic evidence of the relationship between government classifications and lay identification practices before a state-led racial project is initiated in comparison to afterward. To meet this bar, we used unique survey data from Brazil that captured lay identification (open-ended question) and government classification (closed-ended question) from two points in time: before and well after the Brazilian state's move from weak to strong institutionalization of racial categories. Our analytic comparison of these data revealed key shifts in Brazilians' racial subjectivities on the ground in the 
overall direction of increased alignment with government categories across our study's time span. Our analysis showed, however, that the influence of the state's project varied significantly across subsets of the Brazilian population and did so in some ways that were unanticipated, as we address below.

In line with expectations from scholarship on how states make race (Ford 1994; Bailey 2008; Leiberman and Singh 2012, 2017), we observed many more Brazilians adopting the pardo category as their lay racial identification in 2008 compared to 1995 (as indicated by the open-ended survey questions). More specifically, we also found a significant increase during this time span in the likelihood that those Brazilians who choose to identify as pardo when constrained to government categories also choose to identify as pardo when there were no constraints on their self-classification. Our findings thus suggest that these policies acted as what Lieberman and Singh (2017) refer to as a switching mechanism: the policies effectively increased the general salience of pardo as a term of self-identification, and they worked to brighten the boundary that demarcates pardo category membership. Moreover, the effect was strong: We documented a threefold increase in pardo dimension alignment across the study period.

As was the case with pardos, our analysis also shows that dimension alignment increased among brancos between 1995 and 2008. Hence, our analysis suggests that not only can race-targeted approaches brighten the boundaries of targeted populations but they can do so for nontargeted populations as well (Golub 2005; Bailey 2008). In important contrast to pardos, though, there was a decrease overall in the percentage of those self-classifying as branco across time. The increase in branco dimension alignment, along with the overall reduction in the percentage of the population self-classifying as branco, suggests whiter and tighter parameters of Brazilian whiteness across the study period, or its "purification." In a context marked by racialized social stratification and racism, the strengthened demarcation of branco category membership is surely, at the very least, a double-edged sword.

Though likely unintended, the heightened demarcation of pardo and branco category membership works to facilitate the state's continuing administration of its race-targeted policies. The lack of clarity of the boundary separating pardos (beneficiaries) from brancos (nonbeneficiaries) initially caused significant challenges for the implementation of the state's racial quota system (Feres Júnior 2004; Maio and Santos 2005). ${ }^{23}$ As mentioned above, some universities resorted to the use of photographs and racial verification committees to police pardo-branco differentiation, and there have been numerous lawsuits accusing individuals of racial fraud along this boundary cleavage (Peria and Bailey 2014; Lehmann 2018). In strengthening pardo (and branco) category demarcation, Brazil's affirmative-action policies decreased traditional racial ambiguity along the branco-pardo cleavage. In the process, albeit inadvertently, these policies have worked to more fully constitute a (pardo) population category its policies' targeted; moreover, it also may have more fully constituted a nontargeted (branco) population category.

In contrast, our findings show that the government's move to strong institutionalization of the preto term has not led to the preto category's increased resonance for lay identification. In addition, the institutionalization of the preto category did not increase dimension alignment among pretos in 2008 compared to 1995, as was 
the case among pardos and brancos. This finding runs counter to scholarship that predicts the increased salience of categories used by the state to allocate opportunities or resources (Tilly 2004; Bailey 2008; Lieberman and Singh 2012, 2017). It is also worth noting that the lack of resonance of preto for lay identification is not especially consequential for the administration of policies targeting this category. Pretos are a relatively small segment of the Brazilian population (at 7.6 percent in the 2010 census) and a small minority of the population targeted by quotas for nonbrancos in Brazil (approximately 15 percent based on 2010 census data). More significantly, there is no boundary ambiguity between branco and preto for beneficiary identification, as is the case between branco and pardo. This is because branco and preto terms capture opposing poles of the official Brazilian color scheme, which are separated by the intermediate pardo category.

One of the reasons for the contrasting influence of the state's policies across subsets of the Brazilian population is because states do not initiate racial projects tabula rasa. All racial projects intersect with both contemporaneous cultural understandings of society's relevant social cleavages (Bourdieu 1985; Fields 1990) as well as with historical and ongoing parallel racial projects, both national and international, that produce the contemporary context (Nagel 1994; Eschbach et al. 1998; Bailey 2008; Paschel 2016). The Brazilian racial terrain was contoured historically in large part by elite racial projects infused with an ideology of whitening, whose legacies continue to reverberate in Brazilians' racial common sense (de Oliveira e Oliveira 1974; Loveman 2009). Being preto has meant stigmatization, vilification, and discrimination across centuries of Brazilian history; the descriptor preto remains a culturally stigmatized category in Brazil to this day. At the same time, there is a rich vocabulary of alternative terms outside the government's scheme-still along the dark end of the color continuum but in the direction of the ideologically and/or culturally more desirable "mixed" or "whitened" shades-marking nuance in the color continuum but also distance from preto (Sheriff 2001; Sansone 2003). The cultural propensity to manage stigma by avoiding the descriptor preto in favor of other gradational terms in lay identification dynamics is likely one source of resistance to an increased alignment between this particular state racial category and Brazilians' preferred terms of identification on the ground.

Another likely reason for the consistently low salience of the term preto as a preferred lay identification across this period, even in the face of the state's institutionalization of the category for affirmative action, is the Brazilian negro movement's efforts to popularize the term negro as a more desirable, destigmatized, politicized alternative to preto (Nascimento and Nascimento 2001; Sansone 2003). The cultural terrain constituted by the Brazilian state's long history of racial projects informed by ideologies of whitening-as-progress has constituted a battlefield for Brazil's negro movement (de Oliveira e Oliveira 1974; Loveman 2009). This movement seeks to counter whitening's perverse effects through encouraging Brazilians to embrace positive negro racial identification and projecting the diffusion of a negro social identity to all nonbrancos or Afro-Brazilians.

The negro movement's racial project has faced significant resistance on the ground in diffusing its dichotomous racial perspective. Most specifically, the movement has not been successful historically in bridging to its targeted constituency of 
pardos and pretos (Burdick 1998; Telles 2004). Nonetheless, our results suggest that the movement's racial project is gaining traction. For example, we showed a large increase in the percentage of the population choosing negro as their lay identification on the open-ended question between 1995 and 2008 (Figure 2). Although that percentage was small overall in 2008 , at 8 percent of the sample population relative to the negro movement's perspective that approximately 50 percent of the country is negro, its twofold increase across this period was notable and is evidence of the term's growing resonance.

At the same time, however, our data suggest that the increased resonance of negro for lay identification was constrained to the darkest segment of Brazil's nonbranco population; that is, the negro term had become during the study period an increasingly viable lay identification only among pretos (Figure 3). Hence, the negro movement's racial project of advancing negro as a label for positive racial affirmation, as well as its use in some affirmative-action policies, seemed to have tilted the balance between the previously broadly synonymous preto and negro terms (Feres Júnior 2004; Telles 2004) in favor of negro for lay identification. Nonetheless, the growth in the symbolic stature of the negro label was not enough to make it resonant among pardos in 2008. Pardo has long represented population admixture, and as reified by Brazil's whitening ideology, it does not carry the same amount of stigma as the preto or negro labels. Hence, unlike for the heavily stigmatized preto category, the incentive for pardos to embrace negro for lay identification was far from clear in $2008 .{ }^{24}$

The type of racial intermediacy that pardo symbolizes has been a defining social cleavage in Brazil's history (Harris 1970; Degler 1971; de Oliveira e Oliveira 1974; Campos 2013). But racial intermediacy is anathema to the negro movement; indeed, in addition to the influence of the ideology of whitening, negro movement actors have often held that the state's use of the intermediate pardo category in its national census obstructed the development of a unified negro social identity (de Oliveira e Oliveira 1974; Santos 1999). The perceived obstructionist effect of Brazil's historically weak institutionalization of racial intermediacy on collective negro identification could actually be strengthened now that the state has moved to institutionalize the pardo category in more substantial ways, as in fact our findings suggest.

Hence, the state's contemporary race-targeted project seems to be inadvertently solidifying a tripartite racial scheme in Brazil consisting of brancos, pardos, and negros, at least during the period of our study (1995-2008). The strengthening of the symbolic boundaries that demarcate racial intermediacy would be a significant unintended consequence of policies that aimed to acknowledge and address inequality between whites and nonbrancos in Brazil. The increased salience of the intermediate pardo category as a preferred lay identification could also constitute a substantial unanticipated setback to the negro movement's long-term project to encourage nonbranco Brazilians with perceived African origins to unify in their identification as negro. 


\section{Conclusion}

The Brazilian state's unprecedented embrace of race-targeted affirmative action at the turn of the twenty-first century has begun to change how Brazilians racially identify and shift the social relevance of particular racial boundaries relative to others. The Brazilian case thus suggests the power of states to make race-altering the salience of particular lines of vision and division and shifting preferred categories of lay identification - through the institutionalization of racial categories in ways that link them directly to consequential life opportunities, as in the fields of education and employment. At the same time, however, some of the specific shifts in patterns of lay racial identification that are emerging in Brazil were neither intended by those who designed and implemented affirmative action nor anticipated by interested observers. Thus, the Brazilian experience underscores that no state's racial project is enacted tabula rasa; all racial projects unfold upon political and ideological terrain configured by prior histories of struggle, and the interface of historical legacies with contemporary racial projects is a source of contingency and unintended consequences (Fields 1990).

Even as our analysis in this article provides evidence that suggests that the Brazilian state's implementation of race-targeted social policy is changing Brazilians' subjective racial identification on the ground, it could nonetheless be misleading to conclude with the simple statement that "the Brazilian state is making race." Without further elaboration, such a concluding statement could easily be misread as a claim that the state is imposing its own vision of relevant racial divisions in a totally straightforward, predictable, and seamlessly top-down way or that the state is a unified entity that acts autonomously within the political field to advance its own particular ends. Such a conclusion could also be misread as a claim that no other factors beyond the state's institutionalization of racial categories played a role in shifting Brazilians' preferred categories of racial identification in this period. None of these claims is implied or necessary to our central conclusion that the Brazilian state's race-targeted social policies appear to be shifting Brazilians' racial subjectivities.

Rather, the Brazilian state's dramatic turn to race-targeted public policy is an illustrative example of the enactment of a state-led racial project due in good measure to pressure from nonstate actors. In the case of Brazil, these included leaders of the negro movement, allied social scientists and politicians, and supportive international organizations that shared a common lens on the nature of racism and racial inequality and the preferred methods to address them (Bourdieu and Wacquant 1999; Htun 2004; Telles 2004; Bailey 2008; Campos 2013; Loveman 2014; Paschel 2016). In particular, it was the negro movement's political vision and agenda during this period that dramatically bridged to the Brazilian state in terms of transmitting its diagnostic framing on racial inequality and in lobbying the state to intervene. ${ }^{25}$ In fact, the movement's bridging with the state was so successful that many negro movement actors were formally incorporated into state administrative roles at various institutional levels (Maio and Santos 2005; Lehmann 2018). Perhaps most notably, the state created a federal cabinet-level ministry in 2003, the Secretariat for Policies to Promote Racial Equality, whose ministers and related functionaries 
have been prominent negro movement actors. ${ }^{26}$ Hence, the unprecedented turn of the Brazilian state to the strong institutionalization of racial categories reflects the political influence - exerted both from outside the state and, increasingly across this period, from within the state as well—of a social movement and its domestic and international allies.

In sum, the Brazilian state's race-targeted social policies seem to have altered the salience of particular racial boundaries relative to others and shifted patterns of subjective identification while also making race and racial inequality per se more publicly recognized and politically contentious social concerns. The Brazilian state is making race. But it is not doing so in a linear and seamless way nor as an autonomous force acting on society from outside and from above. States institutionalize and naturalize racial divides through society; they do not simply impose them upon society. And the state itself is better construed not as an independent agent of race-making but as a powerful instrument of race-making, as the Brazilian case makes clear. Through the strong institutionalization of racial categories, those who control the administrative apparatus of the state can affect change in the salience of particular lines of racialized division and patterns of subjective identification, but they cannot do so under conditions of their own choosing nor with unlimited control over the cultural and political consequences.

\section{Notes}

1 We use "state" to signal state institutions at various levels of government.

2 Of course, a state's abstinence from racial category institutionalization does not preclude the formation of racial cleavages.

3 See Tilly (2004:220) regarding boundary-making through an "incentive shift."

4 See Emigh et al. (2015) for a critique of the idea that census categories make race from the top down.

5 We focus on self-identification as one important and empirically discernible facet of individual subjectivity. A much larger study would complement analyses of changes in identification patterns on surveys with in-depth, longitudinal, qualitative research attuned to the multifaceted nature of subjectivities.

6 The UNESCO-sponsored studies did, however, document racial prejudice and discrimination in Brazil (Wagley 1952; Bastide and Fernandes 1955).

7 In the U.S. context, Bobo et al. (2012:85) label racial quotas a "strong form of affirmative action" that is "both illegal (except in specific, court-ordered situations) and extremely unpopular" (the latter as measured through surveys of U.S. public opinion). Brazil's Supreme Tribunal of Justice, however, ruled in favor of racial quotas in 2012 (Lehmann 2018); moreover, social surveys from the period under study reveal high levels of support for race-targeted affirmative action among Brazilians irrespective of color and/or race (Bailey 2004).

8 Individuals self-classifying as indigenous (indígena) are targeted in some regions where this small segment of Brazil's population (at less than 0.5 percent) is most concentrated (Lehmann 2018). The two nonbeneficiary census categories are white (branco) and Asian (amarelo, literally "yellow"), at 47.7 percent and 1.1 percent, respectively. 
9 The universities' racial quotas are most often a subcategory of overarching social-class quotas (Peria and Bailey 2014), and the size of the racial component is based on the proportion of pardos and pretos in the local population as registered in the national census (Lehmann 2018).

10 Moreover, when used in affirmative-action policies, the noncensus term negro is now defined officially by the Brazilian state as individuals self-classifying in the state's official census scheme as either pardo or preto (Eurístenes et al. 2016; Feres Júnior et al. 2017).

11 Urban areas accounted for 75.6 percent, 81.2 percent, and 84.4 percent of the Brazilian population in the 1991, 2000, and 2010 censuses, respectively. Municipalities are drawn within macroregions by using probability proportional-to-size sampling; respondents are then selected, adopting quotas for age and gender at sampling points.

12 Weights are included to produce a representative national result. Nevertheless, analyses with and without weights return virtually the same results in both descriptive and multivariate regression analyses. For the sake of simplicity and to avoid pitfalls in the use of weights in regression analysis (Gelman 2007), we report unweighted analyses.

13 In Portuguese: Qual é a sua cor?

14 In Portuguese: Considerando as seguintes categorias, qual é a sua cor: branca, preta, parda, amarela, ou indígena?

15 In Brazil, the minimum wage is a lowest possible salary, defined by the federal government, that employers can pay employees for one month of full-time work.

16 In both samples, 16 years was the minimum age of eligibility to answer the survey. The oldest respondents were 98 and 88 years old in the 1995 and 2008 samples, respectively.

17 As age is not normally distributed, the natural logarithm of age was also included in alternative regression models. As results remained stable across model specifications, we chose to use a zero-to-one age variable for the sake of simplicity.

18 We also tested models in which we interacted government classification with household income and gender. Those interactions, however, were not significant, and we opted to not include them in the final regression models.

19 Because the distribution of variables changes between 1995 and 2008 and because we also pool data from two points in time, the comparison of regression estimates must be interpreted as approximations.

20 These constricting and expanding dynamics are consistent with data from the 2000 and 2010 Brazilian censuses.

21 The negative year coefficient among brancos does not imply a decrease in alignment for this group. The interpretation of coefficients for interactive terms suggests that the difference in the effect of year among brancos and pretos is relative to the effect of year among pardos. For the sake of example, the 1995-to-2008 coefficient is 1.1 for pardos, -0.45 for brancos, and -1.11 for pretos (see the online supplement for the full report of regression results). The year effect is therefore $1.1+(-0.45)=0.65$ for brancos and $1.1+$ $(-1.11)=-0.01$ for pretos

22 The coefficient for the preto-age interaction is significant at the 0.08 level in 2008.

23 See Telles (2002) regarding the branco-pardo boundary ambiguity.

24 Feres Júnior (2004:305), for example, writes that due to the interchangeability of negro and preto in colloquial understanding (during our study period), it would be a stretch to expect pardos to view themselves as negros even if it meant qualifying for quotas exclusively targeting negros in university admission.

25 See Snow et al. (1986) regarding "frame alignment."

26 See http://www. seppir.gov.br/sobre-2/institucional (accessed August 1, 2018). 


\section{References}

Bailey, Stanley R. 2004. "Group Dominance and the Myth of Racial Democracy: Antiracism Attitudes in Brazil." American Sociological Review 69:728-47. https://doi .org/10.1177/ 000312240406900506.

Bailey, Stanley R. 2008. “Unmixing for Race Making in Brazil." American Journal of Sociology 114:577-614. https://doi.org/10.1086/592859.

Bailey, Stanley R. 2009. Legacies of Race: Identities, Attitudes, and Politics in Brazil. Stanford, CA: Stanford University Press.

Bailey, Stanley R., and Edward E. Telles. 2006. "Multiracial versus Collective Black Categories: Examining Census Classification Debates in Brazil." Ethnicities 6:74-101. https://doi . org/10.1177/1468796806061080.

Bailey, Stanley R., Mara Loveman, and Jeronimo O. Muniz. 2013. "Measures of 'Race' and the Analysis of Racial Inequality in Brazil." Social Science Research 42:106-19. https: //doi.org/10.1016/j.ssresearch.2012.06.006.

Bastide, Roger, and Florestan Fernandes.1955. Relações Raciais Entre Negros e Brancos em São Paulo. São Paulo, Brasilia: Anhembi.

Bobo, Lawrence D., Camille Z. Charles, Maria Krysan, and Alicia D. Simmons. 2012. “The Real Record on Racial Attitudes." Pp. 38-83 in Social Trends in the United States: Evidence from the General Social Survey Since 1972, edited by P. V. Marsden. Princeton, NJ: Princeton University Press. https://doi.org/10.1515/9781400845569-005.

Bourdieu, Pierre. 1985. "The Social Space and the Genesis of Groups." Theory and Society 14:723-44. https://doi.org/10.1007/BF00174048.

Bourdieu, Pierre, and Loic Wacquant. 1999. “On the Cunning of Imperialist Reason." Theory, Culture $\mathcal{E}$ Society 16:41-58. https : //doi .org/10.1177/026327699016001003.

Burdick, John. 1998. “The Lost Constituency of Brazil's Black Movements.” Latin American Perspectives 98:136-55. https://doi.org/10.1177/0094582X9802500110.

Burleigh, Michael, and Wolfgang Wippermann. 1993. The Racial State: Germany, 19331945. Cambridge, United Kingdom: Cambridge University Press.

Campos, Luiz Augusto. 2013. “O Pardo Como Dilema Político. “ Insight Inteligência 63:80-91.

Datafolha Instituto de Pesquisas. 1995. “Racismo Cordial." Retrieved April 4, 2018 (http: //www.cis.org.br).

Datafolha Instituto de Pesquisas. 2008. “Racismo Cordial." Retrieved April 4, 2018 (http: //www.cis.org.br).

Davis, F. James. 1991. Who Is Black? One Nation's Definition. University Park, PA: The Pennsylvania State University Press.

Degler, Carl N. 1971. Neither Black nor White: Slavery and Race Relations in Brazil and in the United States. Madison, WI: University of Wisconsin Press.

de Oliveira e Oliveira, Eduardo. 1974. “O Mulato, um Obstáculo Epistemológico.” Argumento 1:65-74.

de Zwart, Frank. 2005. "The Dilemma of Recognition: Administrative Categories and Cultural Diversity." Theory and Society 34:137-69. https://doi.org/10.1007/ s11186-005-6234-3.

Emigh, Rebecca Jean, Dylan Riley, and Patricia Ahmed. 2015. “The Racialization of Legal Categories in the First U.S. Census." Social Science History 39:485-519. https : //doi . org/ 10.1017/ssh.2015.69. 
Emigh, Rebecca Jean, Dylan Riley, and Patricia Ahmed. 2016. Changes in Censuses from Imperialist to Welfare States: How Societies and States Count. Vol. 2. Basingstoke, United Kingdom: Palgrave Macmillan. https ://doi .org/10.1057/9781137485069.

Eschbach, Karl, Khalil Supple, and C. Matthew Snipp. 1998. "Changes in Racial Identification and the Educational Attainment of American Indians, 1970-1990." Demography 35:35-43. https://doi.org/10.2307/3004025.

Eurístenes, Poema, João Feres Júnior, and Luiz Augusto Campos. 2016. “Evolução da Lei no 12.711 nas Universidades Federais (2015)." Pp. 1-24 in Levantamento das Políticas de Ação Afirmativa. Rio de Janiero, Brazil: GEMAA, IESP-UERJ.

Feres Júnior, João. 2004. "Ação Afirmativa No Brasil: Fundamentos e Críticas." Revista Econômica 6:291-312.

Feres Júnior, João, Marcell Machado, Poema Eurístenes, and Luiz Augusto Campos. 2017. "Políticas de Ação Afirmativa nas Universidades Estaduais (2016)." Pp. 1-30 in Levantamento das Políticas de Ação Afirmativa. Rio de Janiero, Brazil: GEMAA, IESP-UERJ.

Fialho, Fabrício. M. 2017. "The Political Psychology of Race in Comparative Perspective: Racial Identity, Attitudes, and Participation in Brazil, South Africa, and the United States." PhD thesis, Department of Political Science, University of California, Los Angeles.

Fields, Barbara. 1990. "Slavery, Race and Ideology in the United States of America." New Left Review 1:95-118.

Fitzgerald, David, and David Cook-Martín. 2014. Culling the Masses: The Democratic Origins of Racist Immigration Policy in the Americas. Cambridge, MA: Harvard University Press. https://doi.org/10.4159/harvard.9780674369665.

Ford, Christopher A. 1994. "Administering Identity: The Determination of 'Race' in Race Conscious Law." California Law Review 82:1231-85. https: //doi . org/10 . 2307/3480910.

Francis, Andrew M., and Maria Tannuri-Pianto. 2015. "Inside the Black Box: Affirmative Action and the Social Construction of Race in Brazil." Ethnic and Racial Studies 38:2771-90. https://doi.org/10.1080/01419870.2015.1077602.

French, Jan Hoffman. 2009. Legalizing Identities: Becoming Black or Indian in Brazil's Northeast. Chapel Hill, NC: University of North Carolina Press.

Freyre, Gilberto. 1959. New World in the Tropics: The Culture of Modern Brazil. New York, NY: Knopf.

Fry, Peter, and Yvonne Maggie. 2004. "Cotas Raciais: Construindo um País Dividido?" Econômica 6:153-61.

Gelman, Andrew. 2007. "Struggles with Survey Regression Modeling." Statistical Science 22:153-64. https://doi.org/10.1214/088342306000000691.

Gelman, Andrew, and Hal Stern. 2006. “The Difference between 'Significant' and 'Not Significant' Is Not Itself Statistically Significant." The American Statistician 60:328-31. https://doi.org/10.1198/000313006X152649.

Goldberg, Chad Alan. 2003. "Haunted by the Specter of Communism: Collective Identity and Resource Mobilization in the Demise of the Workers Alliance of America." Theory and Society 32:725-73. https://doi .org/10.1023/B:RYSO.0000004955.37481.89.

Golub, Mark. 2005. “Plessy as 'Passing': Judicial Responses to Ambiguously Race Bodies in Plessy v. Ferguson." Law and Society Review 39:563-600. https://doi .org/10.1111/j . $1540-5893.2005 .00234$. x.

Guimarães, Antonio S. 2005. "Entre o Medo de Fraudes e o Fantasma das Raças." Horizontes Antropológicos 11:215-7. https://doi.org/10.1590/S0104-71832005000100012. 
Guimarães, Antonio S. 2010. "Entrance into Prestigious Universities and the Performance of Groups That Have Been Discriminated against on the Vestibular: Black Students in the University of São Paulo, 2001-2007." Pp. 59-81 in Growing Gaps: Educational Inequality around the World, edited by P. Attewell and K. S. Newman. Oxford, United Kingdom: Oxford University Press. https ://doi .org/10.1093/acprof : oso/9780199732180.003. 0003.

Haney-López, Ian. 1996. White by Law: The Legal Construction of Race. New York, NY: New York University Press.

Harris, David R., and Jeremiah Joseph Sims. 2002. "Who Is Multiracial? Assessing the Complexity of Lived Race." American Sociological Review 67:614-27. https: //doi .org/ $10.2307 / 3088948$.

Harris, Marvin. 1970. "Referential Ambiguity in the Calculus of Brazilian Racial Identity." Southwestern Journal of Anthropology 26:1-14. https : //doi .org/10.1086/soutjanth. 26 . 1.3629265 .

Harris, Marvin, Josildeth G. Consorte, Joseph Lang, and Bryan Byrne. 1993. "Who Are the Whites? Imposed Census Categories and the Racial Demography of Brazil." Social Forces 72:451-62. https://doi.org/10.1093/sf/72.2.451.

Hasenbalg, Carlos. 1985. "Race and Socioeconomic Inequalities in Brazil." Pp. 25-41 in Race, Class and Power in Brazil, edited by P. M. Fontaine. Los Angeles, CA: Center for Afro-American Studies.

Hochschild, Jennifer L., and Brenna M. Powell. 2008. "Racial Reorganization and the United States Census 1850-1930: Mulattoes, Half-Breeds, Mixed Parentage, Hindoos, and the Mexican Race." Studies in American Political Development 22:59-96. https ://doi .org/10. 1017/S0898588X08000047.

Htun, Mala. 2004. "From 'Racial Democracy' to Affirmative Action: Changing State Policy on Race in Brazil." Latin American Research Review 39:60-89. https://doi .org/10.1353/ lar.2004.0010.

Instituto Brasileiro de Geografia e Estatistica. 2011. “Censo Demográfico 2010." Retrieved August 1, 2018 (http://www.ibge.gov.br/home/estatistica/populacao/censo2010/).

Jenkins, Richard. 1994. "Rethinking Ethnicity: Identity, Categorization and Power." Ethnic and Racial Studies 17:197-223. https://doi .org/10.1080/01419870.1994.9993821.

Kertzer, David I., and Dominique Arel, eds. 2002. Census and Identity: The Politics of Race, Ethnicity, and Language in National Censuses. Cambridge, United Kingdom: Cambridge University Press.

Lehmann, David. 2018. The Prism of Race: The Politics and Ideology of Affirmative Action in Brazil. Ann Arbor, MI: University of Michigan Press. https ://doi .org/10.3998/mpub. 9736376.

Lieberman, Evan S., and Prerna Singh. 2012. “The Institutional Origins of Ethnic Violence." Comparative Politics 45:1-24. https: //doi .org/10.5129/001041512802822860.

Lieberman, Evan S., and Prerna Singh. 2017. "Census Enumeration and Group Conflict: A Global Analysis of the Consequences of Counting." World Politics 69:1-53. https: //doi.org/10.1017/S0043887116000198.

Liebler, Carolyn A., Sonya R. Porter, Leticia E. Fernandez, James M. Noon, and Sharon R. Ennis. 2017. "America's Churning Races: Race and Ethnic Response Changes between Census 2000 and the 2010 Census." Demography 54:259-84. https : //doi .org/10.1007/ s13524-016-0544-0.

Longman, Timothy. 2001. "Identity Cards, Ethnic Self-Perception, and Genocide in Rwanda." Pp. 345-57 in Documenting Individual Identity: The Development of State Practices in the 
Modern World, edited by J. Caplan and J. Torpey. Princeton, NJ: Princeton University Press.

Loveman, Mara. 2009. “The Race to Progress: Census Taking and Nation Making in Brazil (1870-1920)." Hispanic American Historical Review 89:435-70. https ://doi .org/10.1215/ 00182168-2009-002.

Loveman, Mara. 2014. National Colors: Racial Classification and the State in Latin America. Oxford, United Kingdom: Oxford University Press. https ://doi .org/10.1093/acprof : oso/9780199337354.001.0001.

Maio, Marcos Chor. 2001. "UNESCO and the Study of Race Relations in Brazil: Regional or National Issue?" Latin American Research Review 36:118-36.

Maio, Marcos Chor, and Ricardo Ventura Santos. 2005. "Política de Cotas Raciais, os 'Olhos da Sociedade' e os Usos da Antropologia: O Caso de Vestibular da Universidade de Brasília (UNB)." Horizontes Antropológicos 11:181-214. https://doi .org/10.1590/ S0104-71832005000100011.

Mamdani, Mahmood. 2001. When Victims Become Killers: Colonialism, Nativism, and the Genocide in Rwanda. Princeton, NJ: Princeton University Press.

Marx, Anthony. 1998. Making Race and Nation: A Comparison of the United States, South Africa, and Brazil. Cambridge, United Kingdom: Cambridge University Press.

Mitchell, Michael. 1985. "Blacks and the Abertura Democratica." Pp. 95-119 in Race, Class, and Power in Brazil, edited by P. M. Fontaine. Los Angeles, CA: Center for Afro-American Studies.

Mora, G. Cristina. 2014. Making Hispanics: How Activists, Bureaucrats, and Media Constructed a New American. Chicago, IL: University of Chicago Press. https://doi .org/10.7208/ chicago/9780226033976.001.0001.

Morning, Ann. 2008. "Ethnic Classification in Global Perspective: A Cross-National Survey of the 2000 Census Round." Population Research Policy Review 27:239-72. https ://doi . org/10.1007/s11113-007-9062-5.

Nascimento, Abdias do, and Elisa Larkin Nascimento. 2001. "Dance of Deception: A Reading of Race Relations in Brazil." Pp. 105-56 in Beyond Racism: Race and Inequality in Brazil, South Africa, and the United States, edited by C. Hamilton et al. Boulder, CO: Lynne Rienner Publishers.

Nagel, Joane. 1994. "Constructing Ethnicity: Creating and Recreating Ethnic Identity and Culture." Social Problems 41:152-76. https : //doi .org/10.2307/3096847.

Nobles, Melissa. 2000. Shades of Citizenship: Race and the Census in Modern Politics. Stanford, CA: Stanford University Press.

Oliveira, Lucia E., Tereza Cristina N. Araújo, and Rosa Maria Porcaro. 1985. O Lugar do Negro na Força de Trabalho. Rio de Janeiro, Brazil: Instituto Brasileiro de Geografia e Estatistica.

Omi, Michal, and Howard Winant. 1994. Racial Formation in the United States. 2nd ed. New York, NY: Routledge.

Paschel, Tianna S. 2016. Becoming Black Political Subjects: Movements and Ethno-Racial Rights in Colombia and Brazil. Princeton, NJ: Princeton University Press.

Peria, Michelle, and Stanley R. Bailey. 2014. "Remaking Racial Inclusion: Combining Race and Class in Brazil's New Affirmative Action." Latin American and Caribbean Ethnic Studies 9:156-76. https://doi.org/10.1080/17442222.2014.915615.

Posel, Deborah. 2001. "Race as Common Sense: Racial Classification in Twentieth-Century South Africa." African Studies Review 44:87-113. https: //doi .org/10.2307/525576. 
Prewitt, Kenneth. 2002. "Race in the 2000 Census: A Turning Point." Pp. 354-61 in The New Race Question, edited by J. Perlmann and M. M. Waters. New York, NY: Russell Sage Foundation.

Roth, Wendy D. 2016. "The Multiple Dimensions of Race." Ethnic and Racial Studies 39: 1310-38. https://doi.org/10.1080/01419870.2016.1140793.

Sansone, Livio. 2003. Blackness without Ethnicity: Constructing Race in Brazil. New York, NY: Palgrave Macmillan. https ://doi .org/10.1057/9781403982346.

Santos, Thereza. 1999. “The Black Movement: Without Identity There Is No Consciousness or Struggle." Pp. 23-30 in Black Brazil: Culture, Identity, and Social Mobilization, edited by L. Crook and R. Johnson. Los Angeles, CA: University of California, Los Angeles Latin American Center Publications.

Saperstein, Aliya. 2008. “(Re)Modeling Race: Moving from Intrinsic Characteristic to Multidimensional Marker of Status." Pp. 335-49 in Racism in Post-Race America: New Theories, New Directions, edited by C. Gallagher. Chapel Hill, NC: Social Forces Publishing.

Schwartzman, Luisa Farah. 2009. "Seeing Like Citizens: Unofficial Understandings of Official Racial Categories in a Brazilian University." Journal of Latin American Studies 41:221-50. https://doi .org/10.1017/S0022216X09005550.

Sewell, William H. 1996. "Historical Events As Transformations of Structures: Inventing Revolution at the Bastille." Theory and Society 25:841-81. https://doi .org/10.1007/ BF00159818.

Sheriff, Robin E. 2001. Dreaming Equality: Color, Race, and Racism in Urban Brazil. New Brunswick, NJ: Rutgers University Press.

Silva, Nelson V. 1996. “Morenidade: Modo de Usar.” Estudos Afro-Asiáticos 30:79-95.

Snow, David A, E. Burke Rochford, Steven K. Worden, and Robert D. Benford. 1986. “Frame Alignment Processes, Micromobilzation, and Movement Participation." American Sociological Review 51:464-81. https://doi .org/10.2307/2095581.

Suzuki, Kazuko. 2016. Divided Fates: The State, Race, and Korean Immigrants' Adaptation in Japan and the United States. Lanham, MA: Lexington Books.

Telles, Edward E. 2002. "Racial Ambiguity among the Brazilian Population." Ethnic and Racial Studies 25:415-41. https ://doi .org/10.1080/01419870252932133.

Telles, Edward E. 2004. Race in Another America: The Significance of Skin Color in Brazil. Princeton, NJ: Princeton University Press.

Telles, Edward E., and Nelson Lim. 1998. “Does It Matter Who Answers the Race Question? Racial Classification and Income Inequality in Brazil." Demography 35:46574. https: //doi.org/10.2307/3004014.

Tilly, Charles. 2004. "Social Boundary Mechanisms." Philosophy of the Social Sciences 34:211-36. https://doi.org/10.1177/0048393103262551.

University of Brasilia. 2004. "Internal University Policy Statement." Retrieved August 1, 2018 (http://www.cespe.unb.br/vestibular/arquivos/2004-2/ED_2004_2_VEST_ 2004_3_ABT_I.pdf).

Uvin, Peter. 2002. "On Counting, Categorizing, and Violence in Burundi and Rwanda." Pp. 148-75 in Census and Identity: The Politics of Race, Ethnicity, and Language in National Censuses, edited by D. I. Kertzer and D. Arel. Cambridge, United Kingdom: Cambridge University Press.

Wacquant, Loïc. 2002. "From Slavery to Mass Incarceration: Rethinking the 'Race Question' in the US." New Left Review 13:41-60. 
Wagley, Charles. 1952. "Introduction." Pp. 7-15 in Race and Class in Rural Brazil, edited by C. Wagley. Paris, France: UNESCO.

Stanley R. Bailey: Department of Sociology, University of California, Irvine.

E-mail: bailey@uci.edu.

Fabrício M. Fialho: Centre de Recherches Internationales, Sciences Po Paris, France. E-mail: fabriciofialho@gmail.com.

Mara Loveman: Department of Sociology, University of California, Berkeley.

E-mail: mloveman@berkeley.edu. 